\title{
The differentiation potential of adipose tissue-derived mesenchymal stem cells into cell lineage related to male germ cells
}

\author{
[Potencial de diferenciação de células-tronco mesenquimais derivadas do tecido adiposo em células da \\ linhagem germinativa masculina] \\ P. Bräunig, W.G. Glanzner, V.B. Rissi, P.B.D. Gonçalves \\ Universidade Federal de Santa Maria - UFSM - Santa Maria, RS
}

\begin{abstract}
The adipose tissue is a reliable source of Mesenchymal stem cells (MSCs) showing a higher plasticity and transdifferentiation potential into multilineage cells. In the present study, adipose tissue-derived mesenchymal stem cells (AT-MSCs) were isolated from mice omentum and epididymis fat depots. The AT-MSCs were initially compared based on stem cell surface markers and on the mesodermal trilineage differentiation potential. Additionally, AT-MSCs, from both sources, were cultured with differentiation media containing retinoic acid (RA) and/or testicular cell-conditioned medium (TCC). The AT-MSCs expressed mesenchymal surface markers and differentiated into adipogenic, chondrogenic and osteogenic lineages. Only omentum-derived AT-MSCs expressed one important gene marker related to male germ cell lineages, after the differentiation treatment with RA. These findings reaffirm the importance of adipose tissue as a source of multipotent stromal-stem cells, as well as, MSCs source regarding differentiation purpose.
\end{abstract}

Keywords: Gdnf, retinoic acid, somatic stem cell, testicular cell-conditioned medium

\section{RESUMO}

O tecido adiposo é uma fonte apropriada de células-tronco mesenquimais (MSCs), as quais demonstram ampla plasticidade com capacidade de transdiferenciar em diversas linhagens. No presente estudo, as células-tronco mesenquimais derivadas do tecido adiposo (AT-MSC) foram isoladas de tecido adiposo localizado nas regiões próximas ao omento e testículos de camundongos. Primeiramente, as AT-MSCs foram comparadas com base na expressão de marcadores antigênicos de superficie e no potencial de diferenciação nas três linhagens mesodérmicas. Além disso, AT-MSC, de ambas as fontes, foram cultivadas com meio de diferenciação contendo ácido retinóico (RA) e / ou meio condicionado testicular (TCC). As AT-MSCs expressaram marcadores de superficie mesenquimais e diferenciaram nas linhagens adipogênica, condrogênica e osteogênica. Após o tratamento com RA, somente as AT-MSCs isoladas do tecido adiposo depositado na região do omento expressaram um único importante marcador relacionado às células da linhagem germinativa masculina. Estes resultados reafirmam a importância do tecido adiposo como fonte de células-tronco estromais-multipotentes, bem como, uma fonte de MSCs para estudos de diferenciação.

Palavras-chave: Gdnf, ácido retinóico, células-tronco somáticas, meio condicionado testicular

\section{INTRODUCTION}

An area of biological research that generates great optimism is the use of stem cells for the treatment of diseases (Young and Black, 2004; Nayernia et al., 2006). A reliable source of stem

Recebido em 26 de abril de 2016

Aceito em 27 de março de 2017

E-mail: pbraunig@gmail.com cells are the adipose tissue-derived mesenchymal stem cells (AT-MSCs), which are well characterized, easy to isolate, and have already been used for therapeutic applications (Mitchell et al., 2006; Gimble et al., 2007). AT-MSCs are multipotent cells and can be induced to differentiate into all three germ layers, 
developing into bone, cartilage, muscle, heart, and neural cells (Zuk et al., 2002). Therefore the AT-MSCs potential to transdifferentiate into male germ cells should be investigated aiming future cell therapy for infertility.

Adipose tissue is an organ of great heterogeneity and plasticity (Kim and Moustaid-Moussa, 2000). The cellular complexity of adipose tissue can be divided into two different cell fractions: mature adipocytes and the stromal-vascular fraction (SVF). The SVF is highly heterogeneous, containing fibroblasts, endothelial cells, vascular smooth muscle cells, monocytes, hematopoietic cells, and mesenchymal stem cells (Prunet-Marcassus et al., 2006; Schäffler and Büchler, 2007). This cellular fraction can be isolated from adipocytes and maintained in culture. The AT-MSCs expand manifold in culture, reaching high passage numbers and retaining differentiation potential (Bunnell et al., 2008; Zhu et al., 2008).

Animals have diverse fat sources anatomically divided into subcutaneous and internal fat depots (Strem et al., 2005; Bunnell et al., 2008). According to the fat pad location, adipose tissue shows different metabolic properties, genes expression profiles, antigenic features, and differentiation potential, influencing AT-MSCs characteristics (Tchkonia et al., 2002).

AT-MSCs in vitro differentiation has demonstrated promising results (Zuk et al., 2002) and several substances are used for differentiation of mesenchymal stem cells (MSCs) into diverse cell lineages (Schäffler and Büchler, 2007; Mosna et al., 2010), Including retinoic acid (RA), a vitamin A (retinol)derivative, which is widely used as a differentiation inducer of MSCs in male germ cells (Nayernia et al., 2006; Huang et al., 2010) Tan et al., 2016). Furthermore, the conditioned medium obtained from the cell culture supernatants is also a strategy applied in differentiation treatments. The soluble factors present in conditioned medium have been employed for chondrogenic, myogenic, neural, and germ cell differentiation of bone marrowand adipose tissue-derived MSCs (Silva et al., 2013; Stern-Straeter et al., 2013; Han et al., 2014). However, the effect of RA and testicular cell conditioned medium in AT-MSCs differentiation into germ cells should be elucidated.

Analyses of marker gene transcripts allow investigation of AT-MSC differentiation and facilitate the selection of efficient differentiation inducers (Phinney and Prockop, 2007; Schäffler and Büchler, 2007; Hou et al., 2014). The genes commonly investigated to confirm MSCs differentiation into male germ cell are Vasa, Stella, Dazl, Stra8, Nanos2, Plzf, and, in addition, Gdnf which is used as a marker for Sertoli cells (Hou et al., 2014; Chen and Liu, 2015; Ikami et al., 2015).

Taking these observations into consideration, the aims of the present study were to compare ATMSCs, isolated from two different adipose depots in mice, regarding surface markers and trilineage differentiation potential, as well as, to evaluate the expression of relevant gene markers of male germinative cells in AT-MSCs from both sources, after treatments with RA and testicular cell-conditioned medium.

\section{MATERIAL AND METHODS}

Adipose tissue from $11 \mathrm{BALB} / \mathrm{c}$ mice (8 weeks old), was collected from the omentum and epididymis regions. The tissue was, separately, minced and digested in collagenase solution $(1 \mathrm{mg} / \mathrm{mL}$ ) (SIGMA-ALDRICH, USA) for 30min at $37^{\circ} \mathrm{C}$. After digestion, the collagenase solution was inactivated with growth medium (Dulbecco's Modified Eagle Medium-F12 $+10 \%$ fetal bovine serum $+100 \mu \mathrm{g}(100 \mathrm{IU})$ of penicillin and, streptomycin $+0,25 \mu \mathrm{g}$ of amphotericin B) (all Gibco, USA) and the cells were centrifuged (200xg, 10min) to obtain a pellet. The resulting pellet was resuspended in growth medium, and 2 $\mathrm{x} 10^{4}$ cells $/ \mathrm{cm}^{2}$ were cultured in cell culture plates (Corning, USA) in a $5 \% \mathrm{CO}_{2}$ incubator (Thermo Scientific, USA) at $37^{\circ} \mathrm{C}$. The cells were maintained in growth medium and the passages were carried out using trypsin solution $(0.25 \%)$ (SIGMA-ALDRICH, USA) once they achieved $70-80 \%$ confluency.

Testicles from 11BALB/c mouse of 8 weeks old were removed, separately minced and enzymatically digested in collagenase solution $(1 \mathrm{mg} / \mathrm{mL})$ for 30 minutes at $37^{\circ} \mathrm{C}$. Tissue digestion was completed with addition of growth medium for collagenase inactivation, and then 
the tissue homogenate was centrifuged for $10 \mathrm{~min}$ at $200 x \mathrm{~g}$. The resulting pellet was resuspended in growth medium, and $2 \times 10^{4}$ cells $/ \mathrm{cm}^{2}$ were cultured in $5 \% \mathrm{CO}_{2}$ at $37^{\circ} \mathrm{C}$. Seven days after cultures were started, and every 3 days afterward for 30 days, testicular cell-conditioned medium (TCC) was collected. After collection, the TCC was centrifuged $(200 x g, 10 \mathrm{~min})$, and the supernatant was filtered $(0.22 \mu \mathrm{m})$ and stored at $20^{\circ} \mathrm{C}$ until use.

Four AT-MSCs cultures from omentum and epididymis fat depots were analyzed by flow cytometry for the stem cells surface markers CD105, CD73, and CD45 at the passages 2 (P2), 4 (P4), and 7 (P7). Briefly, cells were trypsinized, centrifuged, and then $4 \times 10^{4}$ cells were suspended in Stain Buffer (BD Biosciences, USA) in separate microtubes. Samples were then incubated with the antibodies CD45-FITC $(1.5 \mu \mathrm{g} / \mu \mathrm{L})$, CD73-FITC $(1 \mu \mathrm{g} / \mu \mathrm{L})$, and CD105PE $(1 \mu \mathrm{g} / \mu \mathrm{L})(\mathrm{BD}$ Biosciences, USA) in the dark for $20 \mathrm{~min}$ at $37^{\circ} \mathrm{C}$. After incubation, cells were analyzed using the BD FACSuite flow cytometer (BD Biosciences, USA) and the data obtained were analyzed by FLOWJO software.

Three AT-MSCs cultures, at cell passage number 6 (P6), $4 \times 10^{3}$ cells $/ \mathrm{cm}^{2}$ of omentum and epididymis-derived AT-MSCs were cultured in osteogenic medium $(50 \mu \mathrm{M}$ L-ascorbic acid 2-phosphate, $0.1 \mu \mathrm{M}$ dexametasone, and $15 \mathrm{mM}$ $\beta$-glycerolphosphate) (all SIGMA-ALDRICH, USA), chondrogenic medium $(50 \mu \mathrm{M}$ dexametasone, $\quad 50 \mu \mathrm{M}$ L-ascorbic acid 2-phosphate, $10 \mathrm{ng} / \mathrm{mL}$ TGF- $\beta$, and $1 \mathrm{x}$ insulin-transferrin-sodium selenite) (all SIGMAALDRICH, USA), and with adipogenic medium $(50 \mu \mathrm{M}$ indomethacin, $1 \mu \mathrm{M}$ rosiglitazone, $1 \mu \mathrm{M}$ dexamethasone, and $1 \mu \mathrm{g} / \mathrm{mL}$ insulin) (all SIGMA-ALDRICH, USA), for 21 and 17 days. The media were changed every 3 days and, histological staining was performed after the differentiation periods. Cells induced with osteogenic, adipogenic, and chondrogenic media were first fixed with paraformaldehyde $4 \%$ and then stained with alizarin red $(\mathrm{pH} 4.1)$, oil red, and alcian blue ( $\mathrm{pH}$ 2.5) (all SIGMA-ALDRICH, USA), respectively, and observed using an inverted microscope at magnification $100 \mathrm{X}$ (Leica DMI600B, Germany).

Four AT-MSCs cultures derived from the omentum and epididymis fat pads, at P6 and
$4 \times 10^{3}$ cells $/ \mathrm{cm}^{2}$, were induced by growth medium supplemented with $10^{-6} \mathrm{M}$ RA (group1) (SIGMAALDRICH, USA), or $50 \%$ TCC $+50 \%$ growth medium (group 2), or 50\% growth medium supplemented with $10^{-6} \mathrm{M} \mathrm{RA}+50 \% \mathrm{TCC}$ (group 3) at 7, 14, and 21 days. Adipose tissue-derived cells maintained with only growth medium were used as a control group (group 4). Each group was tested in duplicate. The media were changed every 3 days.

After each period of differentiation treatments into male germ cells $(7,14$, and 21 days), total RNA was isolated from the 4 groups. RNA extraction was performed using Trizol reagent (Invitrogen, USA) according to the manufacturer's instructions. After extraction, RNA concentration and quality were checked by a NanoDrop1000 spectrophotometer (Absorbance of 260/280nm) (Thermo Scientific, USA). Complementary DNA (cDNA) was synthesized using 1000ng of total RNA, which was first treated with $0.1 \mathrm{U}$ of DNase Amplification Grade (Life Technologies, USA) for $5 \mathrm{~min}$ at $37^{\circ} \mathrm{C}$. After DNase inactivation at $65^{\circ} \mathrm{C}$ for $10 \mathrm{~min}$, cDNA was performed in $20 \mu \mathrm{L}$ final volume reaction using the iScript cDNA synthesis Kit (BioRad, USA).

The relative expression levels of specific genes were determined by quantitative PCR (qPCR) conducted in a CFX384 thermocycler (BioRad, USA) using GoTaq qPCR Master Mix (Promega, USA). All primers (Table 1) for analysis of the murine mRNA Vasa, Stella, Dazl, Stra8, Nanos2, Plzf , Gdnf, Gapdh and $\beta$-Actin were designed based on gene sequences deposited in the GenBank database using Primer Express Software (Applied Biosystems, USA).

Melting-curve analyses were performed to verify product identity. To optimize the qPCR assay, serial dilutions of the cDNA templates were used to generate a standard curve. The standard curve was constructed by plotting the $\log$ of the dilution factor against the $\mathrm{Ct}$ value obtained during amplification of each dilution. Reactions with a coefficient of determination (R2) higher than 0.98 and efficiency between $95 \%$ and $105 \%$ were considered optimized. The relative standard curve method was used to quantify transcripts in each sample. Samples were run in duplicate, and results were expressed relative to the average $\mathrm{Ct}$ values for the Gapdh and $\beta$-Actin genes as 
internal controls. A sample of mRNA extracted from mouse testicles was used as a positive control for validating primers and amplicons.
Variation in expression levels was analysed by ANOVA and multiple comparisons between days or groups were performed by LSMeans Student's t test using the JMP Software.

Table1. List of primer sequences and accession numbers for gene sequences used for the mRNA gene expression analysis

\begin{tabular}{cccc}
\hline Gene & Forward primer & Reverse primer & $\begin{array}{c}\text { Accession } \\
\text { number }\end{array}$ \\
\hline Dazl & CGAAGCATACAGACAGTGGTCTCT & TAAGCACTGCCCGACTTCTTCT & 010021.5 \\
Stras & TTGCCGGACCTCATGGAAT & GTGTCACTTCATGTGCAGAGATGAT & 009292.1 \\
Stella & CGGTGCTGAAAGACCCTATAGC & GGCTCACTGTCCCGTTCAAA & 139218.1 \\
Vasa & GGCTGTGTTGCATCTGTTGAC & ATCAACTGGATTGGGAGCTTGT & 001145885.1 \\
Nanos 2 & AGGTAGCTGAGGAGCCCAACTC & TGCTTGCAGAAGTTGCATATGG & 194064.2 \\
Plzf & CGAGCTTCCGGACAACGA & AAATGCATTCTCAGTCGCAAAC & 001033324.2 \\
Gdnf & GATTCGGGCCACTTGGAGTT & GACAGCCACGACATCCCATAA & 010275.2 \\
Gapdh & CAGCCTCGTCCCGTAGACAA & GTAGACCATGTAGTTGAGGTCAATGAA & 008084.2 \\
B- Actin & TCGTGGGCCGCTCTAGGCAC & TGGCCTTAGGGTTCAGGGGG & 007393.3 \\
\hline
\end{tabular}

All procedures using BALB/c mice in the present study were approved by the Institutional Committee for Ethics in Animal Experiments at the Federal University of Santa Maria, RS, Brazil, approval number 087/2014.

\section{RESULTS AND DISCUSSION}

Flow cytometry analysis showed that in omentum-derived AT-MSCs a decrease in double-positive CD105/CD73 cells, and an increase in CD105 and CD73 single-positive cells in P2, P4, and P7 (Figure 1A and Table 2 occurred. While in epididymis-derived ATMSCs there was an increase in cells expressing the double-positive mesenchymal surface markers, as well as an increase in CD105 single positive cells in the same passages mentioned above (Figure 1B and Table 2). In both adipose tissue-derived cultures, cells expressed insignificant levels of the hematopoietic linage marker CD45 (Figure 1A, B and Table 2).

AT-MSCs cultures from two different fat pads in mice, omentum and epididymis, were analyzed by flow citometry and, although the classical mesenchymal surface markers were expressed in cells from both sources, their levels differed between cells from the two adipose sources and among passages (Figure 1A, B and Table 2). These results indicated that adipose tissue isolated from mouse omentum and epididymis regions have different subsets of MSC The immunophenotype results presented in this study are in accordance with studies that relate the variable expression of surface markers to differences in tissue sources, the method of isolation and culture, and species differences (Silva et al., 2013; Prunet-Marcussus et al., 2006; Chamberlain et al., 2007; Schäffler and Büchler, 2007). Interestingly, previous studies have demonstrated that the expression of surface antigens, also shows significant variation during subculture. For example, studies comparing freshly isolated human adipose-derived cells and serially passaged showed a progressive increase in mesenchymal markers like CD90, CD73, and CD29 (Mosna et al., 2010). Similar increases occurred in the present study in the expression of MSC surface markers CD105 and CD73 in ATMSCs derived from epididymis at P2, P4, and P7. Taken together the flow cytometry results obtained in the present study illustrate that stem cell surface antigen expression profiles vary with different cell sources and passages.

The trilineage differentiation protocols were used to induce AT-MSCs, from both mouse fat depots, into bone, cartilage, and fat to further confirm their mesodermal differentiation capacity, and both adipose tissues were able to differentiate into all three linages. Osteogenic and chondrogenic differentiations occurred at 21 days. With chondrogenic differentiation, cells developed a multilayered matrix that was strongly stained with alcian blue, indicating an abundance of glycosaminoglycans in the extracellular matrix (Figure $2 \mathrm{~A}$ and B). ATMSCs in osteogenic medium differentiated into osteoblasts, with calcium accumulation indicated 
by positive staining with alzarin red (Figure $2 \mathrm{~A}$ and B). In adipogenic differentiation, both adipose tissue-derived cultures needed 17 days to differentiate and showed an accumulation of lipid-rich vacuoles within cells. These vacuoles were positively stained by oil red staining (Figure $2 \mathrm{~A}$ and $\mathrm{B}$ ). The AT-MSCs grown in culture medium (undifferentiated) did not show any lipid droplets and maintained their typical fibroblast-like shape (Figure $2 \mathrm{~A}$ and $\mathrm{B}$ ). Therefore, AT-MSCs from both the omentum and epididymis fat sources showed the potential to differentiate into the three mesodermal: adipogenic, osteogenic, and, chondrogenic, lineages.

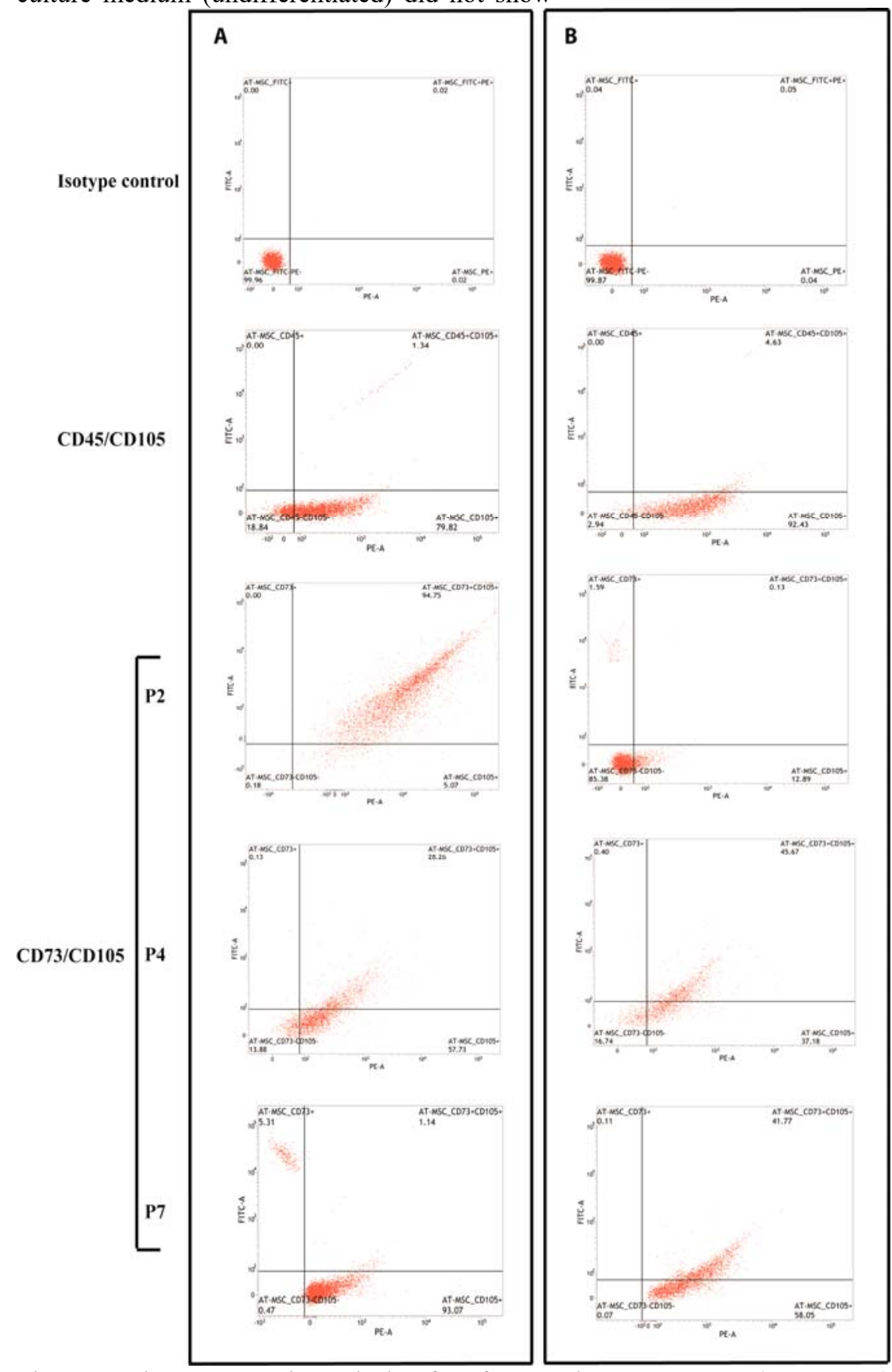

Figure 1. Flow cytometric analysis of surface markers CD73 FITC), CD105 (PE) and CD45 (FITC) in mice omentum A) and epididymis B) derived AT-MSCs at cell passage 2 (P2), 4 (P4) and 7 (P7). 
The differentiation potential...

Table 2. Flow cytometric analysis of MSC markers CD73 and CD105, and hematopoietic marker CD45 expression in mice omentum (A) and epididymis (B) derived AT-MSCs at cell passage 2 (P2), 4 (P4) and 7 (P7)

\begin{tabular}{|c|c|c|c|c|c|c|}
\hline Cell surface marker & $\begin{array}{c}\text { A } \\
\text { P2 }\end{array}$ & B & $\begin{array}{c}\text { A } \\
\text { P4 } \\
\end{array}$ & B & $\begin{array}{r}\text { A } \\
\text { P7 } \\
\end{array}$ & B \\
\hline $\mathrm{CD} 45^{+} / \mathrm{CD} 105^{-}$ & $0.0 \%$ & $0.04 \%$ & $0.28 \%$ & $0.13 \%$ & $0.0 \%$ & $0.0 \%$ \\
\hline $\mathrm{CD} 45^{\circ} / \mathrm{CD} 105^{+}$ & $99.31 \%$ & $12.55 \%$ & $77.07 \%$ & $76.73 \%$ & $79.82 \%$ & $92.43 \%$ \\
\hline $\mathrm{CD} 45^{+} / \mathrm{CD} 105^{+}$ & $0.67 \%$ & $0.18 \%$ & $8.38 \%$ & $8.43 \%$ & $1.34 \%$ & $4.63 \%$ \\
\hline $\mathrm{CD} 73^{+} / \mathrm{CD} 105^{-}$ & $0.0 \%$ & $1.59 \%$ & $0.13 \%$ & $0.40 \%$ & $5.31 \%$ & $0.11 \%$ \\
\hline $\mathrm{CD} 73^{-} / \mathrm{CD} 105^{+}$ & $5.07 \%$ & $12.89 \%$ & $57.73 \%$ & $37.18 \%$ & $93.07 \%$ & $58.05 \%$ \\
\hline $\mathrm{CD} 73^{+} / \mathrm{CD} 105^{+}$ & $94.75 \%$ & $0.13 \%$ & $28.26 \%$ & $45.67 \%$ & $1.14 \%$ & $41.77 \%$ \\
\hline
\end{tabular}
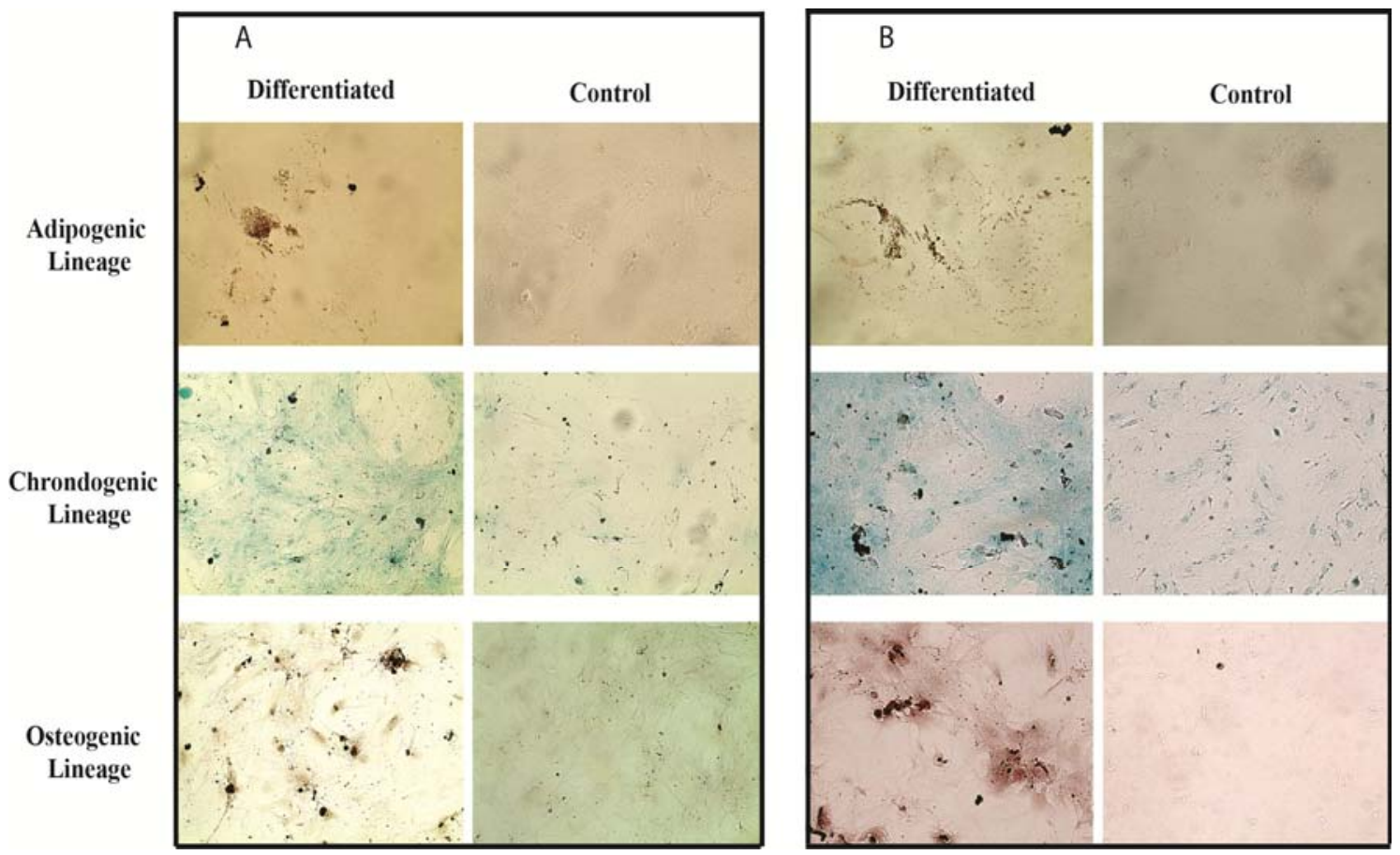

Figure 2. Adipogenic (oil red), osteogenic (alizarin red), and, chondrogenic (alcian blue) differentiation of mice omentum A) and epididymis B) derived- AT-MSCs. (100X magnification).

Since different fat pads have their own metabolic characteristics, fatty acid compositions, and gene expressions (Tchkonia et al., 2002; Schäffler and Büchler, 2007), the source of adipose tissue might be expected to influence AT-MSCS characteristics, such as surface markers and differentiation potential. Therefore, additional studies are necessary to properly understand the molecular characteristics, as well as the plasticity, of the AT-MSCs isolated from different fat depots.

A qPCR assay was performed to determine the expression levels of germinative markers ( $\mathrm{Dazl}$, Stella, Stra8, Vasa, Nanos2, Plzf and Gdnf) in RA and TCC MSC-treated cells. Amongst the
AT-MSCs sources (epididymal and omental), $G d n f$ was the only gene that demonstrated detectable expression level, and its expression observed only in omentum-derived AT-MSCs treated with RA differentiation media, after incubation periods of, 7, 14, and 21 days (Figure 3). Conversely, no detectable expression was detected in AT-MSCs maintained in TCC medium for any period of treatment (Figure 3) similar to untreated AT-MSCs (Figure 3). The qPCR results demonstrated that RA stimulated $G d n f$ expression in omentum-derived AT-MSCs, therefore, indicating that RA was the main factor involved in $G d n f$ expression. 


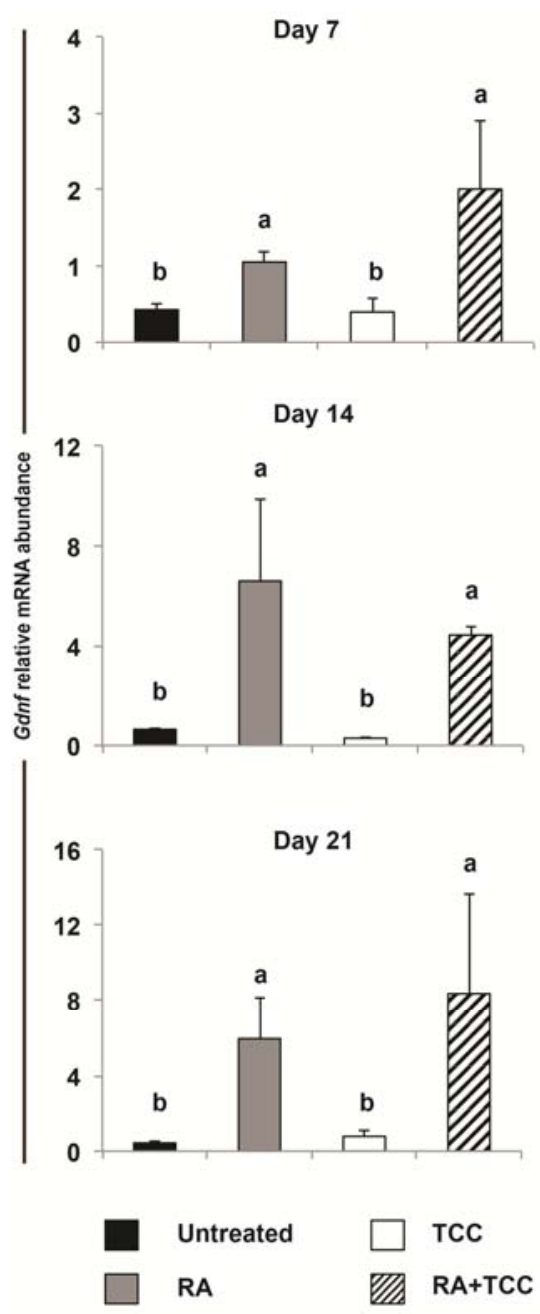

Figure 3. Relative expression of the murine $G d n f$ gene in omentum AT-MSCs treated with retinoic acid (RA), testicular cell-conditioned medium (TCC), or RA+TCC for 7, 14, and 21 days, or with growth medium only for an untreated control group. Values with different superscripts $(\mathrm{a}, \mathrm{b})$ are significantly different $(\mathrm{P}<0.05)$.

An active derivative of vitamin A, RA influences germ cell differentiation and is required for the transition to meiosis in both female and male germ cells (Koubova et al., 2006). RA alone has usually been used to promote the differentiation of ESCs and MSCs into germ cells (Geijsen et al., 2004; Nayernia et al., 2006; Drusenheimer et al., 2007; Kerkis et al., 2007). However, RA has been used in association with other substances to induce neuronal differentiation from cultured mouse AT-MSCs (Bi et al., 2010; Pavlova et al., 2012).
RA receptors (RARs) are expressed in both Sertoli and germ cells (Esklid et al., 1991), and RA functions inside the nucleus, recognizing two different classes of RARs. Both classes (RARs and RXRs) are encoded by distinct genes, and they transduce RA signals by binding directly to RA-responsive elements (Rossi and Dolci, 2013). Therefore, based on the effect of RA on $G d n f$ gene expression showed in this study, ATMSCs respond to RA stimulation.

RA receptors (RARs) are expressed in both Sertoli and germ cells (Esklid et al., 1991), and RA functions inside the nucleus, recognizing two different classes of RARs. Both classes (RARs and RXRs) are encoded by distinct genes, and they transduce RA signals by binding directly to RA-responsive elements (Rossi and Dolci, 2013). Therefore, based on the effect of RA on $G d n f$ gene expression showed in this study, ATMSCs respond to RA stimulation.

Retinoids are involved in the regulation of testicular functions, which appear to be necessary for spermatogenesis (Livera et al., 2002) and previous studies have indicated that RA favors spermatogonial differentiation through direct action on spermatogonia and indirect action mediated by changes in the expression of GDNF secreted by Sertoli cells in the testicular niche influencing the self-renewal of spermatogonial stem cells (SSCs) and inhibiting their differentiation. The Gdnf gene is mainly expressed in Sertoli cells, considered, therefore, a marker for this cell line. (Rossi and Dolci, 2013; Chen and Liu, 2015; Ikami et al., 2015).

The testes are abundant sources of numerous hormones and growth factors, such as bone morphogenic protein 4 (BMP4), leukemia inhibitory factor (LIF), basic fibroblast growth factor (bFGF), stem cell factor (SCF), growth differentiation factor-9 (GDF9), and testosterone, all of which are needed for the development of male germ cells (Takabayashi et al., 2001; Pellegrini et al., 2003). Recent studies have shown that TCC supports the differentiation of ESCs into germ cells (Lacham-Kaplan et al., 2006). However, in the present study, TCC alone was not effective promoting expression of germinative markers maybe, due the inappropriate concentration of the soluble factors. Therefore, it seems that TCC might be 
used in combination with other induction factors or might be concentrated to promote cellular differentiation.

MSCs are considered the most plastic adult stem cells and their potential to differentiate has broadly been demonstrated (Zuk et al., 2002; Schäffler and Büchler, 2007); however, there are not studies considering the AT-MSCs differentiation into Sertoli cell. Although previous studies have shown that MSCs maintained in media containing RA differentiate into male germ cells (Nayernia et al., 2006; Drusenheimer et al., 2007; Zhang et al., 2014) and that TCC contributed to this differentiation (Huang et al., 2010; Kaviani et al., 2014) additional gene expression and other analyses should be performed to confirm whether the ATMSCs treated in the present study, differentiate into cell lineage related to male germ cells.

\section{CONCLUSIONS}

Adipose tissue from omentum and epididymis fat depots represents source of AT-MSCs with different characteristics. The fat pad location had a significant influence on AT-MSCs differentiation potential. Between the omental and epididymal sources of adipose tissue in mouse, only AT-MSCs isolated from the adipose tissue deposited on omental region expressed $G d n f$, an important gene related to Sertoli cells, after differentiation treatment with retinoic acid.

\section{REFERENCES}

BI, Y.; GONG, M.; ZHANG, X. et al. Pre-activation of retinoid signaling facilitates neuronal differentiation of mesenchymal stem cells. Dev. Growth Differ., v.52, p.419-431, 2010.

BUNNELL, B.A.; FLAAT, M.; GAGLIARDI, C. et al. Adipose-derived stem cells: Isolation, expansion and differentiation. Methods, v.45, p.115-120, 2008.

CHAMBERLAIN, G.; FOX, J.; ASHTON, B.; MIDDLETON, J. Concise review: mesenchymal stem cells: their phenotype, differentiation capacity, immunological features, and potential for homing. Stem Cells, v.25, p.2739-2749, 2007.

CHEN, S.R.; LIU, Y.X. Regulation of spermatogonial stem cell self-renewal and spermatocyte meiosis by Sertoli cell signaling. Reproduction, v.149, p.159-167, 2015.
DRUSENHEIMER, N.; WULF, G.; NOLTE, J. et al. Putative human male germ cells from bone marrow stem cells. Soc. Reprod. Fertil. Suppl., v.63, p.69-76, 2007.

ESKILD, W.; REE, A.H.; LEVY, F.O. et al. Cellular localization of mRNAs for retinoic acid receptoralpha, cellular retinol-binding protein, and cellular retinoic acid-binding protein in rat testis: evidence for germ cell-specific mRNAs. Biol. Reprod., v.44, p.5361, 1991.

GEIJSEN, N.; HOROSCHAK, M.; KIM, K. et al. Derivation of embryonic germ cells and male gametes from embryonic stem cells. Nature, v.427, p.148-154, 2004.

GIMBLE, J.M.; KATZ, A.J.; BUNNELL, B.A. Adipose-derived stem cells for regenerative medicine. Circ. Res., v.100, p.1249-1260, 2007.

HAN, C.; SONG, L.; LIU, Y. et al. Rat cortex and hippocampus-derived soluble factors for the induction of adipose-derived mesenchymal stem cells into neuron-like cells. Cell Bio Int., v.38, p.768-776, 2014.

HOU, J.; YANG, S.; YANG, H. et al. Generation of male differentiated germ cells from various types of stem cells. Reproduction, v.147, p.179-188, 2014.

HUANG, P.; LIN, L.M.; WU, X.Y. et al. Differentiation of human umbilical cord Wharton's jelly-derived mesenchymal stem cell into germ-like cells in vitro. J. Cell Biochem., v.109, p.747-754, 2010.

IKAMI, K.; TOKUE, M.; SUGIMOTO, R. et al. Hierarchical differentiation competence in response to retinoic acid ensures stem cell maintenance during mouse spermatogenesis. Dev. Stem cells Regen., v.142, p.1582-1592, 2015.

KAVIANI, M.; EZZATABADIPOUR, M.; NEMATOLLAHI-MAHANI, S.N. et al. Evaluation of gametogenic potential of vitrified human umbilical cord Wharton's jelly-derived mesenchymal cells. Cytotherapy, v.16, p.203-212, 2014.

KERKIS, A.; FONSECA, S.A.S.; SERAFIM, R.C. et al. In vitro differentiation of male mouse embryonic stem cells into both presumptive sperm cells and oocytes. Cloning Stem Cells, v.9, p.535-548, 2007.

KIM, S.; MOUSTAID-MOUSSA, N. Secretory, endocrine and autocrine/paracrine function of the adipocyte. J. Nutr., v.130, p.3110-3115, 2000

KOUBOVA, J.; MENKE, D.B.; ZHOU, Q. et al. Retinoic acid regulates sex-specific timing of meiotic initiation in mice. Proc. Natl Acad. Sci. USA., v.103, p.2474-2479, 2006. 
LACHAM-KAPLAN, O.; CHY, H.; TROUNSON, A. Testicular cell conditioned medium supports differentiation of embryonic stem cells into ovarian structures containing oocytes. Stem cells, v.24, p.266273, 2006.

LIVERA, G.; ROUILLER-FABRE, V.; PAIRAULT, C. et al. Regulation and perturbation of testicular functions by vitamin A. Reproduction, v.124, p.173180, 2002.

MITCHELL, J.B.; MCLNTOSH, K.; ZVONIC, S. et al. Immunophenotype of human adipose-derived cells: temporal changes in stromal-associated and stem cell associated markers. Stem Cells, v.24, p.376-385, 2006.

MOSNA, F.; SENSEBÉ, L.; KRAMPERA, M. Human bone marrow and adipose tissue mesenchymal stem cells: a user's guide. Stem Cells Dev., v.19, p.1449-1470, 2010.

NAYERNIA, K.; NOLTE, J.; MICHELMANN, H.W. et al. In vitro differentiated embryonic stem cells give rise to male gametes that can generate offspring in mice. Dev. Cell, v.11, p.125-132, 2006.

PAVLOVA, G.; LOPATINA, T.; KALININA, N. et al. In vitro neuronal induction of adipose-derived stem cells and their fate after transplantation into injured mouse brain. Curr. Med. Chem., v.19, p.5170-5177, 2012

PELLEGRINI, M.; GRIMALDI, P.; ROSSI, P. et al. Developmental expression of BMP4/ALK3/SMAD5 signaling pathway in the mouse testis: A potential role of BMP4 in spermatogonia differentiation. J. Cell Sci., v.16, p.3363-3372, 2003.

PHINNEY, D.; PROCKOP, D.J. Concise review: mesenchymal stem/multipotent stromal cells: the state of transdifferentiation and modes of tissue repaircurrent views. Stem Cells, v.25, p.2896-2902, 2007.

PRUNET-MARCASSUS, B.; COUSIN, B.; CATON, D. et al. From heterogeneity to plasticity in adipose tissues: site- specific differences. Exp. Cell Res., v.312, p.727-736, 2006.

ROSSI, P.; DOLCI, S. Paracrine mechanisms involved in the control of early stages of mammalian spermatogenesis. Front Endocrinol., v.4, p.1-8, 2013.
SCHÄFFLER, A.; BÜCHLER, C. Concise review: adipose tissue-derived stromal cells - basic and clinical implications for novel cell-based therapies. Stem Cells, v.25, p.818-827, 2007.

SILVA, M.L.A.; COSTA-PINTO, A.R.; MARTINS, A. et al. Conditioned medium as a strategy for human stem cells chondrogenic differentiation. J. Tissue Eng. Regen. Med., v.8, p.714-723, 2013.

STERN-STRAETER, J.; BONATERRA, G.A.; JURITZ, S. et al. Evaluation of the effects of different culture media on the myogenic differentiation potential of adipose tissue or bone marrow-derived human mesenchymal stem cells. Int. J. Mol. Med., v.33, p.160-170, 2013.

STREM, B.M.; HICOK, K.; ZHU, M. et al. Multipotential differentiation of adipose tissue derived stem cells. Keio J. Med., v.54, p.132-141, 2005

TAKABAYASHI, S.; SASAOKA, Y.; YAMASHITA, M. et al. Novel growth factor supporting survival of murine primordial germ cells: evidence from conditioned medium of ter fetal gonodal somatic cells. Mol. Reprod. Dev., v.60, p.384-396, 2001.

TAN, H.; WANG. J.J.; CHENG, S.F. et al. Retinoic acid promotes the proliferation of primordial germ cell-like cells differentiation from mouse skin-derived stem cells in vitro. Theriogenology, v.85, p.408-418, 2016.

TCHKONIA, T.; GIORGADZE, N.; PIRTSKHALAVA, T. et al. Fat depot origin affects adipogenesis in primary cultured and cloned human preadipocytes. Am. J. Physiol. Regul. Integr. Comp. Physiol., v.282, p.1286-1296, 2002.

YOUNG, H. E.; BLACK, A. C. JR. Adult stem cells. Anat Rec, v.276A, p.75-102. 2004.

ZHANG, D.; LIU, X.; PENG, J. et al. Potential sprematogenesis recovery with bone marrow mesenchymal stem cells in an azoospermic rat model. Int. J. Sci., v.15, p.13151-13165, 2014.

ZHU, Y.; TIANQING, L.; SONG, K. et al. Adiposederived stem cell: a better stem cell than BMSC. Cell Biochem. Funct., v.26, p.664-675, 2008.

ZUK, P.A.; ZHU. M.; ASHJIAN, P. et al. Human adipose tissue is a source of multipotent stem cells. Mol. Biol. Cell., v.13, p.4279-4295, 2002. 